\title{
Transfusion Practice and Costs in a Tertiary Pediatric Intensive Care Unit
}

\author{
Referans Üçüncü Basamak Pediatrik Yoğun Bakım Ünitesinde Transfüzyon \\ Uygulaması ve Maliyetleri
}

\author{
Gülhan Atakul, @Fahri Yüce Ayhan, DSevgi Topal, Mustafa Çolak, Ekin Soydan, \\ (1) Pınar Seven, DHasan Ağın
}

Health Sciences University, Dr. Behçet Uz Children's Diseases and Surgery Training and Research Hospital, Pediatric Intensive Care Unit, Izmir, Turkey

\section{ABSTRACT}

Aim: In this study we aimed to evaluate transfusion related costs in a pediatric intensive care unit, taking into consideration previously defined transfusion indications, evidence-based transfusion evaluations and clinical transfusion practices.

Material and Method: Seventy six patients that received a blood transfusion in our tertiary referal centre's pediatric intensive care unit between January 2017 - January 2018 were included in the study. Transfusion related costs and total healthcare costs were retrospectively collected. Consumables (blood transfusion set, apheresis set etc.), immunohematological tests and blood transfusion procedure related costs were separately evaluated, an overall transfusion cost per patient was estimated and proportioned to the total health care cost per patient.

Results: The ratio of transfusion related costs within total healthcare costs was found to be $3.24 \%$. The median total healthcare cost and transfusion related cost were 5478.76 Euros (IQR=11280.02) and 130.57 Euros (IQR=354.86), respectively. A significantly strong positive correlation was detected between the number of transfusions and total healthcare cost $(r: 0.674, p<0.01)$. Although the median costs of the patients administered split blood were lower, the difference was not statistically significant.

Conclusion:There are no studies evaluating blood transfusions and costs in pediatric intensive care units in Turkey. More detailed studies are needed to examine transfusion costs and the diversity of blood product transfusions in intensive care units.

Keywords: Pediatric intensive care unit, blood transfusion, transfusion cost, pediatrics

\section{$\ddot{\mathrm{OZZ}}$}

Giriş: Bu çalışmada, çocuk yoğun bakım ünitesinde transfüzyonla ilişkili maliyetleri, daha önce iyi tanımlanmış kan transfüzyon endikasyonlarını ve transfüzyon uygulamalarını; pediatrik transfüzyon kararı verme için kanıta dayalı değerlendirmeyi dikkate alarak tartışmayı amaçladık.

Gereç ve Yöntem: Bir yıllık dönemde (Ocak 2017-Aralık 2017) çocuk yoğun bakım ünitesinde kaldığı süre boyunca kan bileşenleri ile transfüzyon yapılan 76 hasta çalışmaya dahil edildi. Çocuk yoğun bakım ünitesinde tedavi gören çocuklara yönelik sağlık hizmetleri için transfüzyonla ilişkili maliyetler ve toplam maliyet hastane bilgi sistemi kullanılarak toplandı. Sarf malzemelerine (kan transfüzyonu ve aferez setleri gibi), immünohematolojik testler ve kan transfüzyonu prosedürlerine bağlı olarak transfüzyonla ilişkili maliyetler ayrı ayrı ele alındı ve her hasta için transfüzyon maliyeti tahmin edildi ve sonuç olarak sağlık hizmetlerinin toplam maliyetine oranlandı.

Bulgular: Transfüzyona bağlı maliyetin toplam sağlık hizmeti maliyetine oranı \%3,24 olarak bulundu. Hastane maliyeti ve transfüzyonla ilişkili maliyet için medyanlar sırasıyla 5478.76 euro $(\mathrm{IQR}=11280.02)$ ve 130.57 euro $(\mathrm{IQR}=354.86)$ idi. Transfüzyon sayıları ile çocuk yoğun bakım ünitesinin hastaneye yatış maliyeti arasında anlamlı ve güçlü bir pozitif korelasyon tespit edildi ( $r$ : 0,674, $p<0,01)$. Çalışmamızda bölünmüş kan uygulanan hastaların ortanca değerleri daha düşük olmasına rağmen anlamlı bir fark bulunmadı.

Sonuçlar: Türkiye'de çocuk yoğun bakım ünitelerinde kan transfüzyonlarını ve maliyetlerini değerlendiren çalışma bulunmamaktadır. Yoğun bakımlarda transfüzyon maliyetlerini ve kan ürünü transfüzyonlarının çeşitliliğini inceleyen daha ayrıntılı çalışmalara intiyaç vardır.

Anahtar Kelimeler: Çocuk yoğun bakım ünitesi, kan transfüzyonu, transfüzyon maliyet, pediatri 


\section{INTRODUCTION}

Blood transfusion - a special type of tissue transplantation, is one of the most common clinical treatment applications. The World Health Organization (WHO) Global Database on Blood Safety (GDBS) reports that 92 million units of blood were donated in 2011 (1). Transfusion rates for blood components in hospitalized children remains uncertain (2). Although mostly used for life-saving interventions, unnecessary use of blood transfusion may be life-threatening. Pediatric transfusion guidelines are limited and differ in applications. However, it is widely utilized by pediatricians owing to its effect on both oxygen transport capacity of erythrocytes and its hemodynamic benefits (3). Pediatric transfusion guidelines differ from adults mainly due to the differing growth and development stages of children. The formation of pediatric transfusion guidelines is difficult due to limited data on transfusion indications and their outcomes. Therefore, transfusion decisions generally rely on the clinical findings (4). Although not widely accepted as standard practice in children, patient blood management (PBM) is an evidence-based practice that aims to improve patient outcomes by maintaining hemoglobin concentration, optimizing hemostasis, and minimizing blood loss (5). Complications caused by unnecessary transfusions and the treatment of these complications leads to direct and indirect financial burden (6). In addition to the avoidance of transfusionrelated adverse events, PBM also supports costeffectiveness by reducing transfusion-related costs (7-9).

In this study we aimed to evaluate transfusion related costs in a pediatric intensive care unit (PICU), taking into consideration defined transfusion indications, evidencebased transfusion evaluations and clinical transfusion practices (10).

\section{MATERIAL AND METHOD}

This retrospective cost analysis study was conducted at a tertiary pediatric centre's PICU. Data of children aged 1 month to 18 years admitted to PICU between January 2017 and January 2018 were included in the study. The study was approved by the local ethics board (Date: 2019, Decision No: 358). All procedures were carried out in accordance with the ethical rules and the principles of the Declaration of Helsinki. Due to national regulations, regional blood centres run by the Turkish Red Cross provide all blood products except for granulocyte concentrations collected by apheresis at the hospital's apheresis centre.

Splitting of transfusions into smaller amounts using a sterile connector (Terumo BCT, Japan) and gamma irradiation, when required, was conducted at the hospital's transfusion centre. All transfusions were given to critically ill children in a level 3 PICU.
Transfusion related and total cost data were obtained from the hospital information system (HIS) database. Data collected and analysed included patients' age, gender, length of hospitalization, patient comorbidities, indication for PICU admittance, type of blood component transfused and blood type.

Consumables (blood transfusion set, apheresis set etc.), immunohematological tests and blood transfusion procedure related costs were separately evaluated, an overall transfusion cost per patient was estimated and proportioned to the total health care cost per patient.

\section{Statistical Analysis}

SPSS Statistics (IBM Corp. Released 2013. IBM SPSS Statistics for Windows, Version 22.0. Armonk, NY, USA) software was used for statistical analysis. Nonparametric tests (MannWhitney $U$ test, Kruskal-Wallis test, Chi-square analysis, Spearman correlation analysis) were used because the data were not normally distributed (Shapiro-Wilk Test).

\section{RESULTS}

During the study period, blood transfusions were performed in 76 of 210 (36.2\%) patients interned in the PICU. Demographic data, diagnosis at hospitalization and indication for PICU admission of 76 patients included in the study are given in Table 1. A total of 388 blood components were transfused. Of these, 217 were red blood cell (RBC) concentrates, 112 were apheresis platelet concentrates (APC), 6 were granulocyte concentrates (GC), 51 were fresh frozen plasmas (FFP), 1 was cryoprecipitate (Cryo) and 1 was whole blood (WB). Blood component splitting was performed in 150 of RBCs (69\%), 60 of APCs (53\%) whereas 32 of FFPs supplied from the regional blood center were pediatric bags (Figure 1).

The most common indication for RBC transfusion was high risk of developing symptomatic anemia with a hemoglobin $<7 \mathrm{~g} / \mathrm{dL}$ without any other medical treatment likely to correct the anemia, followed by symptomatic anemia. The most common indication for thrombocyte transfusion was active bleeding or $<50 \times 10^{9} /$ I before a surgical procedure, followed by Plt $<20 \times 10^{9} /$.

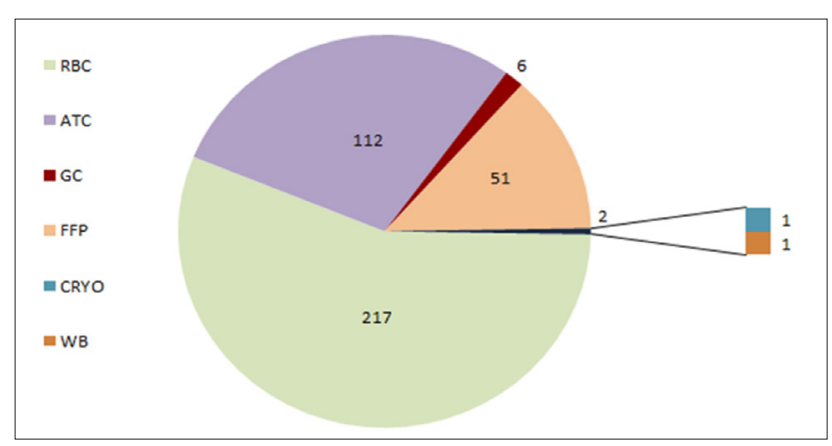

Figure 1. Blood components transfused in PICU patients

RBC: Red Blood Cell, ATC: Apheresis Platelet Concentrates, GC: Granulocyte Concentrates, FFP: Fresh Frozen Plasmas, CRYO: Cryoprecipitate, WB: Whole Blood 


\begin{tabular}{|c|c|}
\hline Demographics & $n=76$ \\
\hline Gender & n (\%) \\
\hline Male/Female & $36(47.4) / 40(52.6)$ \\
\hline Age & Median; (IQR) \\
\hline Months & $12 ;(26)$ \\
\hline Hospitalization time & Median; (IQR) \\
\hline Day & $16(30)$ \\
\hline Primary Diagnoses & n (\%) \\
\hline Chronic lung disease & $7(9.2)$ \\
\hline Cardiovascular disease & $11(14.5)$ \\
\hline Hematological-Oncological & $11(14.5)$ \\
\hline Metabolic Disease & $13(17.1)$ \\
\hline Healthy Child (without chronic disease) & $7(9.2)$ \\
\hline Norological disease & $27(35.5)$ \\
\hline PICU admission diagnoses & n (\%) \\
\hline Respiratory failure & $29(38.2)$ \\
\hline Cardiac failure & $13(17.1)$ \\
\hline Septic Shock & $17(22.4)$ \\
\hline Metabolic Crisis & $5(6.6)$ \\
\hline Post-operative surgery & $1(1.3)$ \\
\hline Norological disease & $11(14.5)$ \\
\hline Length of stay & $\mathbf{n}$ \\
\hline Day & $12 / 9$ \\
\hline Blood groups & n (\%) \\
\hline $\mathrm{ARh}+$ & 25 (32.9) \\
\hline $\mathrm{BRh}+$ & $13(17.1)$ \\
\hline $0 \mathrm{Rh}+$ & $23(30.3)$ \\
\hline $\mathrm{AB}$ Rh+ & $3(3.9)$ \\
\hline A Rh- & $3(3.9)$ \\
\hline B Rh- & $2(2.6)$ \\
\hline $0 \mathrm{Rh}-$ & $6(7.9)$ \\
\hline AB Rh- & $1(1.3)$ \\
\hline
\end{tabular}

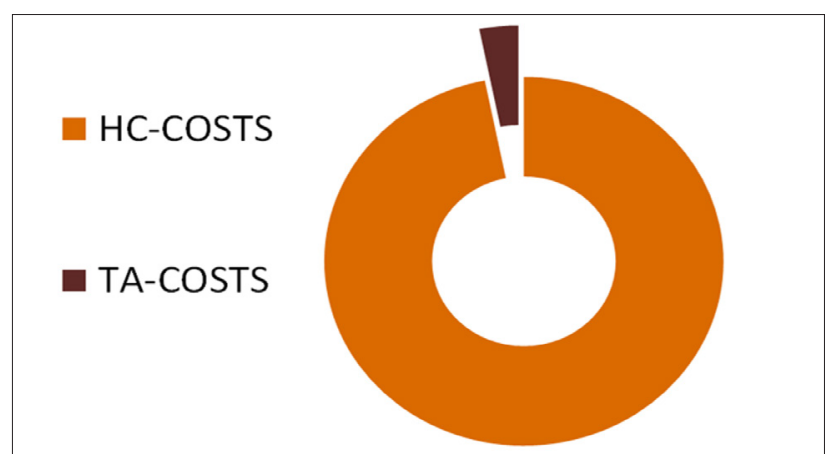

Figure 2. Healthcare costs and transfusion-associated costs proportions HC: Healthcare, TA: Transfusion-associated
Average hemoglobin and hematocrit levels in patients receiving RBS transfusion were $6.90 \pm 0.80$ ve $21.31 \pm 2.79$ respectively. Average thrombocyte count of patients receiving thrombocyte transfusion was $19406 \pm 8601$. Average fibrinogen level in patients receiving FFP transfusion was $160 \pm 61$ and average neutrophil count in patients receiving granulocyte transfusion was $<500$ cells $/$.

Transfusion related costs were calculated taking into account blood transfusion sets, apheresis sets, blood type grouping, cross typing, coombs test and transfusion related procedures (Table $\mathbf{2}$ ). The ratio of transfusion cost to total health care cost was found to be $3.24 \%$ (Figure 2).

Patients were grouped according to the ratio of transfusion related cost to total health care cost: group $1(0-5 \%)$, group $2(5-10 \%)$, group $3(10-15 \%)$ and group $4(>15 \%)$. The number of patients per group was $63.2 \%$ $(n=48), 13.2 \%(n=19), 11.8 \%(n=9)$ and $11.8 \%(n=9)$ respectively.

Median total cost and transfusion related cost was calculated to be 5478.76 Euros (IQR: 11280.02) and 130.57 Euros (IQR: 354.86).

When compared to patients with metabolic or neurological disease, those with hematologicaloncological pathologies had a statistically significantly higher ratio of transfusion related cost to total health care cost ratio $(p=0.012)$. Therefore grouping was conducted as: 1) Patients with hematolojical-oncological pathologies 2) others. Relationship between cost rates, gender of patients and use of pediatric packs is summarized in Table 3.

\section{Tablo 2. Transfusion-associated costs analysis}

\begin{tabular}{lc} 
Costs Data & Costs (=Euro) \\
\hline Transfusion sets & 431.64 \\
Transfusion services & 571.19 \\
Crossmatch & 617.31 \\
Blood products & $16,512.88$ \\
Apheresis sets & $7,973.47$ \\
Total transfusion costs & $26,106.51$ \\
Total healthcare costs & $804,802.38$ \\
\hline
\end{tabular}

Tablo 3. Analysis between cost and gender, pediatric blood product and diagnosis

\begin{tabular}{|c|c|c|c|c|}
\hline \multirow[t]{2}{*}{ Groups } & \multicolumn{2}{|c|}{ Transfusion costs } & \multicolumn{2}{|c|}{ Total costs } \\
\hline & Median (IQR) & $\mathrm{p}$ & Median (IQR) & $\mathrm{p}$ \\
\hline Gender & & 0.643 & & 0.423 \\
\hline Male & 994.87 (2019.17) & & $36351.53(77042.52)$ & \\
\hline Female & $722.03(2955.52)$ & & 31246.23 (39099.1) & \\
\hline Pediatric packages & & 0.414 & & 0.362 \\
\hline Used & 740.99 (2030.28) & & 29125.35 (70753.64) & \\
\hline Unused & $3572.23(5521.71)$ & & $48612.34(210412.52)$ & \\
\hline Diagnoses & & $<0.01^{*}$ & & 0.914 \\
\hline Hematological-Oncological & $5790.87(6224.21)$ & & 36637.98 (67014.79) & \\
\hline Other diagnoses & $678.15(1700.14)$ & & 33036.93 (70587.48) & \\
\hline QR: Interquartile Range & & & & \\
\hline
\end{tabular}


A statistically significant and strong positive correlation was observed between the number of transfusions in PICU and hospitalization costs $(r: 0.674, p<0.01)$. A statistically significant weak positive correlation was found between transfusion cost and hospitalization cost ( $r: 0.247, p=0.032$ ), and also between age and transfusion related cost $(r: 0.227, p=0.048)$.

While there was a significant and strong positive correlation between length of stay (LOS) and total cost of PICU ( $p<0.01, r: 0.695)$, there was no correlation between transfusion related cost and LOS ( $p>0.05)$.

\section{DISCUSSION}

The transfusion of blood and blood products is widely practiced yet rarely discussed as a clinical topic. Whatever the indication, expected clinical improvement, possible alternatives to transfusion and a benefit-risk analysis of transfusion must be performed before a transfusion is performed. Transfusion criteria can vary between clinics. Clinicians in the study centre follow current literature and take into consideration hemodynamic variables and blood parameters of critically ill patients during the blood transfusion decision making process. In a report by the Pediatric Intensive Care Transfusion and Anemia Expertise Initiative (TAXI), a hemoglobin level of $<5 \mathrm{~g} / \mathrm{dl}$ is highlighted as a threshold value due to an increase in mortality below this level, however, there remains uncertainty of the risk-benefit for transfusion when hemoglobin $(\mathrm{Hb})$ is between $5-7 \mathrm{~g} /$ dl. In addition, although $\mathrm{Hb}$ concentration should be accepted as a measure of the body's oxygen status in critically ill patients, it is important to note that it should not be used alone as an indication for RBC transfusion $(11,12)$.

The most frequently used threshold value accepted for the indication of transfusion, the transfusion rates in critically ill pediatric patients and the amount of incentive clinicians take to decrease complication rates are causes for concern. A multicentered study conducted on adult intensive care units reported that transfusion rates decreased without leading to an effect on general mortality (13). Another study concluded that a lower minimum threshold value could be tolerated when making a decision on RBC transfusion (14). Furthermore, it has been reported that the use of a restrictive transfusion protocol may be a better strategy for prolonging survival (15). The average $\mathrm{Hb}$ of patients at transfusion in our study was $6.9 \mathrm{~g} / \mathrm{dl}$. We believe the variations in our results are due to the diagnosis of our critically ill patients and their hemodynamic as well as respiratory parameters. As reported in literature, severe anemia $(\mathrm{Hb}<5 \mathrm{~g} / \mathrm{dl}$ or $\mathrm{Htc}<15 \%)$ is an absolute indication for transfusion due to a significant increase in mortality in these patients $(11,12,16)$. Hemodynamic status is important in critically ill pediatric patients and therefore the threshold value for transfusion may change. Threshold values may be higher in patients with cardiac pathologies and those with sepsis where an increase in tissue oxygenation is required (17).

A multicentered study of thrombocyte transfusion conducted in 2018 reported that thrombocyte transfusions were mostly indicated for prophylaxis and administered when Plt count was < 20 x 109/I (18). In our study, prophylactic thrombocyte transfusion was administered when Plt count was $<20 \times 109 /$ after considering the clinical status of the patient, requirement for surgery, the presence of major or minor bleeding and requirement for extracorporeal treatment.

An evidence-based RBC transfusion guideline regarding transfusion threshold in hematology-oncology patients was published in 2019 by TAXI. The guideline stated that more data regarding RBC transfusion indications, risks, benefits and transfusion alternatives are required in hematology-oncology patients that require frequent transfusions (19). Our study revealed higher transfusion costs in patients with an underlying chronic disease. Apart from hematological pathologies, the presence of chronic pulmonary disease was found to be associated with higher costs. Lengthy recovery times and frequent hospitalization lead to prolonged hospitalization in these patients. Prolonged hospitalization may increase transfusion requirements especially when sepsis is present. As expected, our study revealed the highest cost in patients with hematological diseases.

In-hospital transfusion reactions were calculated to have cost 933,356 Euros in Holland in 2018, with nonserious reactions making up two-thirds of all transfusion reactions and only a third of reactions leading to an increase in hospitalization length (20). Although the length of hospitalization and care as well as cost including medication may vary, it is estimated that RBC transfusions cost 100,000,000 USD in Turkey per year (21). Some studies have reported that these additional costs may affect the general cost of blood transfusions $(22,23)$. As all blood products did no require irradiation, we excluded intravenous access, management of adverse reactions, nursing care and irradiation costs were excluded in our study. Transfusion related side effects and the cost of their management was not included in our study, involving all patients receiving a transfusion for a period of 1 year. During this time-frame, one patient received intravenous antihistamines due to erythema during erythrocyte transfusion. Hospitalization length was not affected therefore the additional cost was disregarded.

It is important to emphasize that, unlike adults, calculating transfusion requirements in smaller amounts, such as in milliliters versus units may also lead to a decrease in 
transfusion related costs. Although the median cost of patients treated with split blood were lower in our study, the difference was not significant. However, the number of non-pediatric blood products in our pediatric centre was low. Statistical analysis could only be performed when the number of non-pediatric blood products are higher.

Patient blood management (PBM) is thought to be beneficial in transfusion practices. This approach entails the prevention of complications, decrease in costs and more importantly the more effective use of the patients blood reserve. A single-centred study from Germany examined the impact of this approach on clinical outcomes and costs. The study reported that PBM combined RBC transfusion with many alternatives leading to improved clinical outcomes and that PBM costs vary between institutes and are determined by the extent to which PBM is utilized (24). It is possible to define blood products and transfusions, ensure their safe application, manage blood transfusion side effects and decrease costs through hospital hemovigilance teams. A study performed in 2016 reported that while not a primary aim of hemovigilance teams, the management and documentation of blood products by these teams lead to advantages regarding costs (25).

\section{CONCLUSION}

Blood transfusions, frequently used in PICUs lead to an increase in health care costs. Clinicians and hospitals must be aware of the financial burden they put on their respective health care system. Many clinicians may choose to perform a blood transfusion in critically ill children independent of current guidelines and without performing a risk-benefit analysis due to the ease of access to blood products. Further studies are required to create strong guidelines for clinicians to follow and to accurately define transfusion thresholds as well as risk and benefits of these thresholds. Such guidelines may also aid in decreasing transfusion related and overall health care costs.

\section{Study Limitations:}

Some parameters that may effect accurate cost calculation such as intravenous lines, management of adversse reactions, nursing services, irradiation etc were not included in cost calculation. Our study is also limited by a small number of patients and its retrospective design.

\section{ETHICAL DECLARATIONS}

Ethics Committee Approval: The study was approved by Health Sciences University, Dr. Behçet Uz Children's Diseases and Surgery Training and Research Hospital Ethic Committee (Date: 2019, Decision No: 358).
Informed Consent: Because the study was designed retrospectively, no written informed consent form was obtained from patients.

Referee Evaluation Process: Externally peer-reviewed.

Conflict of Interest Statement: The authors have no conflicts of interest to declare.

Financial Disclosure: The authors declared that this study has received no financial support.

Author Contributions: All of the authors declare that they have all participated in the design, execution, and analysis of the paper, and that they have approved the final version.

Acknowledgements: The authors would like to thank Mrs. Hafize S., from our institutes transfusion centre, for her support in collecting patient data.

\section{REFERENCES}

1. World Health Organization, Global database on blood safety 2011, http://www.who.int/bloodsafety/global_database/GDBS Summary_Report_2011.pdf; 2011 [accessed June 2011]

2. Teruya J. Red blood cell transfusion in infants and children: Selection of blood products, https://www.uptodate.com/ contents/red-blood-cell-transfusion-in-infants-and-childrenselection-of-blood-products;2020 [accessed August 2020]

3. Cholette JM, Noronha SA, Seghatchian J et al. Indications for red cell transfusions in pediatric patients. Transfus Apher Sci. 2018;57(3):342-6.

4. Gibson BE, Todd A, Roberts I et al. British Commitee for Standards in Haematology Transfusion Task Force: Writing group. Transfusion guidelines for neonates and older children. $\mathrm{Br} J$ Haematol. 2004;124(4):433-53.

5. Goobie SM, Gallagher T, Gross I. Society for the advancement of blood management administrative and clinical standards for patient blood management programs. 4th edition (pediatric version) Pediatric Anesthesia. 2019;29:231-6.

6. Trentino KM, Farmer SL, Swain SG et al. Increased hospita costs associated with red blood cell transfusion. Transfusion. 2015;55(5):1082-9.

7. Leahy MF, Hofmann A, Towler S et al. Improved outcomes and reduced costs associated with a health-system-wide patient blood management program: a retrospective observational study in four major adult tertiary-care hospitals. Transfusion. 2017;57(6): 1347-58.

8. Goel R, Cushing MM, Tobian AA. Pediatric Patient Blood Management Programs: Not Just Transfusing Little Adults. Transfus Med Rev. 2016;30(4):235-41.

9. Hofmann A, Ozawa S, Farrugia A et al. Economic considerations on transfusion medicine and patient blood management. Best Pract Res Clin Anaesthesiol. 2013;27(1):59-68.

10. Lacroix J, Hébert PC, Hutchison JS, et al. TRIPICU Investigators; Canadian Critical Care Trials Group; Pediatric Acute Lung Injury and Sepsis Investigators Network. Transfusion strategies for patients in pediatric intensive care units. N Engl J Med. 2007;19;356(16):1609-19.

11. Doctor A, Cholette JM, Remy KE et al. Pediatric Critical Care Transfusion and Anemia Expertise Initiative (TAXI); Pediatric Critical Care Blood Research Network (BloodNet), and the Pediatric Acute Lung Injury and Sepsis Investigators (PALISI) Network Recommendations on RBC Transfusion in General Critically III Children Based on Hemoglobin and/or Physiologic Thresholds From the Pediatric Critical Care Transfusion and Anemia Expertise Initiative. Pediatr Crit Care Med. 2018;19(9S Suppl 1):98-113.

12. Valentine SL, Bembea MM, Muszynski JA, et al. Consensus Recommendations for RBC Transfusion Practice in Critically II Children From the Pediatric Critical Care Transfusion and Anemia Expertise Initiative. Pediatr Crit Care Med. 2018;19(9):884-98. 
13. Hébert PC, Wells G, Blajchman MA et al. A multicenter, randomized, controlled clinical trial of transfusion requirements in critical care Transfusion Requirements in Critical Care Investigators, Canadian Critical Care Trials Group. N Engl J Med. 1999;11;340(6):409-17.

14. Carson JL, Stanworth SJ, Roubinian N et al. Transfusion thresholds and other strategies for guiding allogeneic red blood cell transfusion. Cochrane Database Syst Rev. 2016;12;10(10):CD002042.

15. M. E. Açık, H. Ş. Türk, C. T. Işıl et al. Frequency and threshold of the erythrocyte suspension transfusion in the intensive care unit. Med Bull Sisli Etfal Hosp. 2014; 48(4): 291-5

16. Lackritz EM, Hightower AW, Zucker JR et al. Longitudina evaluation of severely anemic children in Kenya: the effect of transfusion on mortality and hematologic recovery. AIDS. 1997;11(12):1487-94.

17. Williams GD, Bratton SL, Ramamoorthy C. Factors associated with blood loss and blood product transfusions: a multivariate analysis in children after open-heart surgery. Anesth Analg. 1999;89(1):57-64.

18. Nellis ME, Karam O, Mauer E, et al. Platelet Transfusion Practices in Critically III Children. Crit Care Med. 2018;46(8):1309-17.

19. Steiner ME, Zantek ND, Stanworth SJ, et al. Recommendations on RBC Transfusion Support in Children With Hematologic and Oncologic Diagnoses From the Pediatric Critical Care Transfusion and Anemia Expertise Initiative. Pediatr Crit Care Med. 2018;19(9S Suppl 1):149-56.

20. Janssen MP, van Tilborgh AJW, de Vooght KM et al. Direct costs of transfusion reactions - an expert judgement approach. Vox Sang. 2018;113(2):143-51.

21. Oge $\mathrm{T}$, Kilic $\mathrm{CH}$, Kilic GS. Economic impact of blood transfusions: balancing cost and benefits. Eurasian J Med. 2014;46(1):47-9.

22. Crémieux PY, Barrett $B$, Anderson K et al. Cost of outpatient blood transfusion in cancer patients. J ClinOncol 2000;18(14): 2755-61.

23. Agrawal S, Davidson N, Walker M et al. Assessing the total costs of blood delivery to hospital oncology and haematology patients. CurrMedResOpin 2006;22(10): 1903-9.

24. Kleinerüschkamp AG, Zacharowski K, Ettwein C et al. Costanalysis of patient blood management. Anaesthesist. 2016;65(6):438-48.

25. Decadt I, Costermans E, Van de Poel $M$ et al. A haemovigilance team provides both significant financial and quality benefits in a University Hospital. Transfus Apher Sci. 2017;56(2):199-205. 